\title{
The movements of Alpine glaciers throughout the last 10,000 years as sensitive proxies of temperature and climate changes
}

\author{
Walter Kutschera ${ }^{1, *}$, Gernot Patzelt $^{2}$, Joerg M. Schaefer ${ }^{3}$, Christian Schlüchter ${ }^{4}$, Peter Steier $^{1}$, and Eva Maria Wild ${ }^{1}$ \\ ${ }^{1}$ VERA Laboratory, Faculty of Physics, University of Vienna, A-1090 Vienna, Austria \\ ${ }^{2}$ Gernot Patzelt, Patscher Strasse 20, A-6080 Innsbruck-Igls, Austria \\ ${ }^{3}$ Joerg M. Schaefer, Geochemistry, Lamont-Doherty Earth Observatory, Pallisades, NY 10964-8000, USA \\ ${ }^{4}$ Christian Schlüchter, Institute of Geological Sciences, University of Bern, CH-3012 Bern, Switzerland
}

\begin{abstract}
A brief review of the movements of Alpine glaciers throughout the Holocene in the Northern Hemisphere (European Alps) and in the Southern Hemisphere (New Zealand Southern Alps) is presented. It is mainly based on glacier studies where ${ }^{14} \mathrm{C}$ dating, dendrochronology and surface exposure dating with cosmogenic isotopes is used to establish the chronology of advances and retreats of glaciers. An attempt is made to draw some general conclusions on the temperature and climate differences between the Northern and Southern Hemisphere.
\end{abstract}

\section{Introduction}

It is well known that the Holocene, i.e. the geological time period following the end of the Last Ice Age, enjoyed relatively stable temperatures. But glaciers are sensitive proxies to even small temperature and/or climate changes. Thus, the globally observed retreat of Alpine glaciers and polar ices sheets since about $1850 \mathrm{AD}$ (the end of the socalled Little Ice Age and interrupted by three re-advances) has been linked to the temperature increase caused by human activities, particularly due to the continuous increase of the $\mathrm{CO}_{2}$ concentration in the atmosphere [1]. It is interesting to note that a change in the surface temperature on Earth with increasing $\mathrm{CO}_{2}$ concentration in the atmosphere was already discussed more than 100 years ago by the Swedish chemist and Nobel Laureate Svante Arrhenius [2]. Discussions are ongoing now to define a new geological period called "Anthropocene" [3, 4], where man's influence on the environment is significant and distinct $[5,6]$. Even though the global retreat of glaciers since 1850 is considered to be a fingerprint of man's influence on the climate, it is now evident that considerable glacial fluctuations occurred already much earlier during the Holocene, when human impact was negligible.

In a way, the interest in Alpine glaciers of the past started with the accidental discovery of the famous Iceman Ötzi in 1991, a naturally mummified body which was well preserved for 5200 years in the icy environment of a high mountain pass (3210 $\mathrm{m}$ a.s.1.) in the Ötztal Alps [7-9]. Since then, several forward and backward movements of glaciers in the European Alps and in the New Zealand Southern Alps throughout the last 10,000 years have been established with the help of dendrochronology, radiocarbon dating, surface exposure dating of rocks and moraines with various cosmogenic radionuclides $\left({ }^{10} \mathrm{Be}\right.$, ${ }^{14} \mathrm{C},{ }^{26} \mathrm{Al},{ }^{36} \mathrm{Cl}$ ), and geomorphological considerations [1022].

The atmospheric $\mathrm{CO}_{2}$ concentration was remarkably constant during the last 10,000 years, changing by only 20 ppm [1]. Such small $\mathrm{CO}_{2}$ variations are unlikely to trigger the observed glacier movements. It is therefore possible that small solar activity variations [23], enhanced by (hitherto largely unknown) feed-back processes on Earth caused the observed glacial fluctuations [24]. Whatever the cause of these natural fluctuations, they constitute a "background" which is now being modified in a complex way by human activities. The challenge is then to evaluate the human signal correctly, and try to make predictions about the climate in the near future [25]. There is an ongoing discussion about the certainties and uncertainties of these predictions [e.g. 26]. In spite of great efforts around the world to reduce anthropogenic $\mathrm{CO}_{2}$ emissions, it appears doubtful whether this is currently more than a "pious wish" [27].

The current work cannot give an answer to these important questions. Rather it will present evidence for the waxing and waning of Alpine glaciers in both the Northern and Southern Hemispheres throughout the Holocene. An attempt will be made to explain at least some of these fluctuations from first principles. Even though the complexity of the climate may only allow crude estimates of those principles, we simply follow the advice of the late Murray Gell-Man: "Nature is most easily described by a sequence of approximations," [28]. 


\section{Paleorecord of Temperature and $\mathrm{CO}_{2}$}

The records of temperature and atmospheric $\mathrm{CO}_{2}$ concentration on Earth show considerable variation over the last 500 million years (Fig. 1). In particular, the $\mathrm{CO}_{2}$ concentration during the time of the dinosaurs $(\sim 240-65$ million years ago) was around $1000 \mathrm{ppm}$, and the mean temperature about $6{ }^{\circ} \mathrm{C}$ warmer than today. From Fig. 1, one can see that during the last 10 million years, a gradual lowering of the temperature and of the $\mathrm{CO}_{2}$ concentration occurred.

Around 2.5 million years ago (beginning of the Pleistocene), major glaciations in both Antarctica and Greenland set in. The record of ice cores from Antarctica currently goes back 800,000 years [29, 30], and shows the well-known Milankovic cycles of the ice ages first discovered in the $\delta^{18} \mathrm{O}$ record of foraminifera in deep-sea sediment cores [31]. Efforts to drill ice cores in Antarctica back to 1.5 million years are under way $[32,33]$. Except for the brief interglacial periods, the $\mathrm{CO}_{2}$ concentration stays at its lowest value in this period and reaches about $200 \mathrm{ppm}$ at the glacial maximum 20,000 years ago. After warming up to the Holocene some 10,000 years ago, both relatively stable temperature and $\mathrm{CO}_{2}$ concentrations persist. The rapid increase of $\mathrm{CO}_{2}$ during the last 60 years from about $300 \mathrm{ppm}$ to currently $415 \mathrm{ppm}$ is well documented [1].

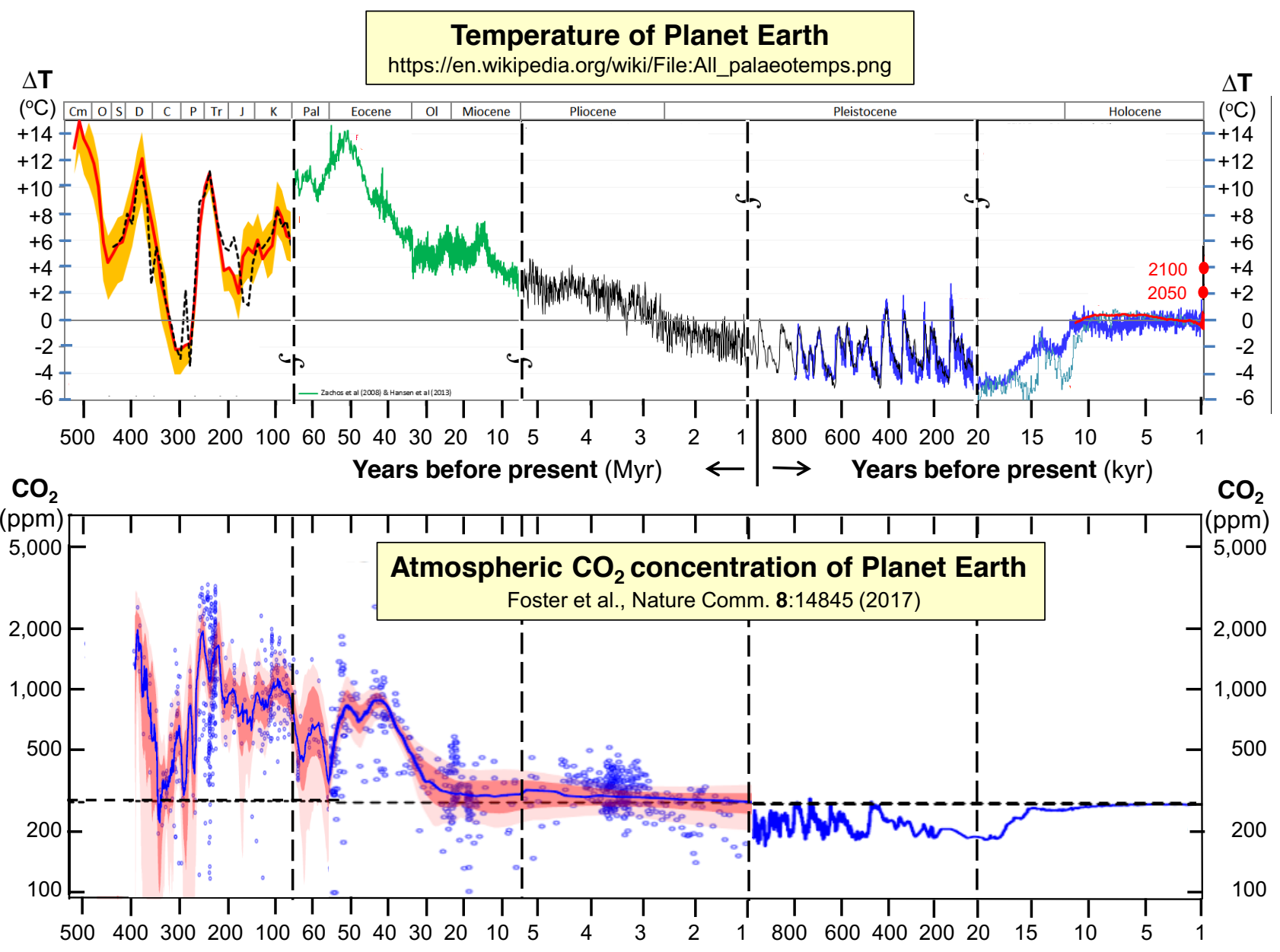

Figure 1. Summary of temperature and $\mathrm{CO}_{2}$ concentrations on Earth for the last 500 million years. The figure is a composite from the original temperature record [34] and the $\mathrm{CO}_{2}$ record [35]. The $\mathrm{CO}_{2}$ record was adjusted to the same time scale as the temperature record. Possible temperature increase in 2050 and 2100, respectively, predicted by some climate models are indicated with red dots on the rightmost temperature axis.

\section{Movement of Alpine glaciers during the Holocene}

The accidental discovery of the Iceman "Ötzi" in 1991 [79], and the appearance of human artefacts and natural materials released from receding Alpine glaciers [22], evolved into a new field sometimes called "glacial archaeology". Besides the archaeological aspect in the study of glaciers, there is the sensitivity to small climate changes which became apparent through multiple periods of forward and backward movements of glaciers throughout the Holocene [11]. 


\subsection{The European Alps}

Glacier movements of the past have been studied in many mountain ranges of the European Alps [10,11, 13-15, 17, 19-22]. In $2001,{ }^{14} \mathrm{C}$ dating of a variety of organic materials released from glaciers in the Swiss Alps revealed eight Holocene phases of reduced glacier extent: 99109550 , 9010-7980, 7250-6500, 6170-5950, 5290-3870, $3640-3360,2740-2620$, and 1530-1170 calibrated years $\mathrm{BP}(\mathrm{BP}=$ before present $=1950 \mathrm{AD})[11]$. In the following we discuss a few selected cases of glacier movements in the European Alps.

\subsubsection{The Pasterze glacier}

The rapidly receding glaciers in our time sometimes release well-preserved subfossil trees, which can be dated with ${ }^{14} \mathrm{C}$ and dendrochronology. Surprisingly, up to 10,000-year old logs were found in the forefield of the Pasterze glacier, the largest glacier in the Austrian Alps [10], The situation of the finds is depicted in Fig. 2. This indicated that in the Early Holocene these glaciers were even smaller than today, allowing trees to grow in an area still covered by ice today.
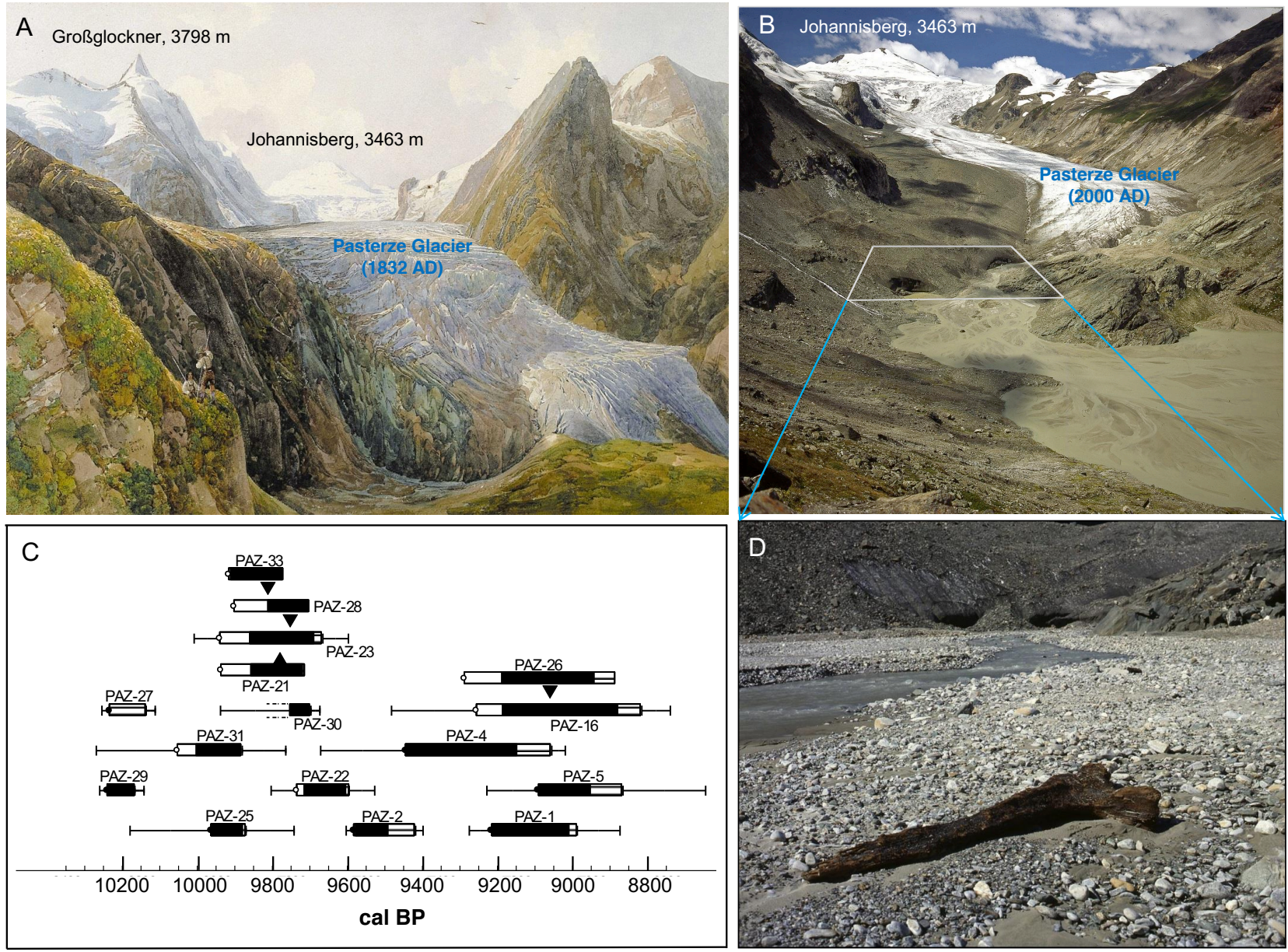

Figure 2 Old wood found in the forefield of the Pasterze Glacier in the Austrian Alps. The dramatic loss of glacier mass can be assessed from the painted landscape of 1832 (A) and the photo of the twindling glacier in 2000 (B). Panel (D) zooms into the trapezoidal section of (B) and shows one log found in the forefield of the glacier. Panel (C) shows the age distribution of all wood specimens collected from the glacier forefield [10] by combining dendro dating (filled sections) with ${ }^{14} \mathrm{C}$ measurements (error bars indicate $65 \%$ calibrated age ranges). The open sections depict missing inner tree-ring sections, and the hatched sections indicate compressed wood. This composite figure is reproduced from Ref. [22].

\subsubsection{Ice cores at Mount Ortles and Monte Rosa}

A recent ice core from the summit of Mt. Ortles in South Tyrol (3859 $\mathrm{m}$ a.s.1.) revealed that the deepest ice near bedrock is about 7000 years old [36]. "Absence of older ice on the highest glacier of South Tyrol is consistent with the removal of basal ice from bedrock during the Northern Hemisphere Climatic Optimum (6-9 kyrs BP), the warmest interval in the European Alps during the Holocene" [36]. A somewhat different result was reported from an ice core at Col Gnifetti (4455 m a.s.1.) in the Monte Rosa mountain range of Switzerland, where the deepest ice sample of this high-altitude glacier indicated an age of about 10,000 years [37]. The higher altitude as compared to Mt. Ortles may have prevented the loss of basal ice during the Climatic Optimum mentioned above. 


\subsubsection{The Rhone glacier}

Exposure dating of rock surfaces on Earth by measuring in-situ produced cosmogenic radioisotopes [38, 39] with Accelerator Mass Spectrometry (AMS) has made it possible to date glacially polished rock surfaces and glacial moraines. Application of this method allowed one to reconstruct the dynamic history of many glaciers in the European Alps, and in other glacial regions around the world. In particular, if the concentration of two radioisotopes with very different half-lives are measured, the ratio of these radioisotopes allows one to reconstruct the chronology of glaciers including erosion of the underlying bedrock. Such measurements were performed with ${ }^{14} \mathrm{C}\left(\mathrm{t}_{1 / 2}=5.7 \mathrm{kyr}\right)$ and ${ }^{10} \mathrm{Be}(1.39 \mathrm{Myr})$ in quartz grains of recently exposed rock surfaces of the Rhone Glacier [17], which was one of the dominant glaciers of the European Alps during the Last Ice Age. In addition,
${ }^{26} \mathrm{Al}(0.72 \mathrm{Myr})$ was also measured in the samples. Concordant exposure ages for ${ }^{10} \mathrm{Be}$ and ${ }^{26} \mathrm{Al}$ allowed one to make the assumption that the Rhone Glacier removed several meters of rock during the last Ice Age, leaving the sampled bedrock surfaces (Fig. 3) most likely free of cosmogenic nuclides at the beginning of the Holocene period. Consequently, the measured cosmogenic nuclide concentration in the sampled material integrates the periods when these rocks were ice-free during the Holocene. Since some erosion of the rocks happened also during the Holocene, the ${ }^{10} \mathrm{Be}$ exposure ages shown in Fig. 3, decrease toward the lowest, central part of the glacial trough, where ice velocity was greatest and thus erosion rate is expected to be fasted. The longest exposure times ( 4.5 to $5.3 \mathrm{kyr}$ ) were found at the left-lateral margin zone of the glacier indicating the longest integral time when the glacier was smaller than today.

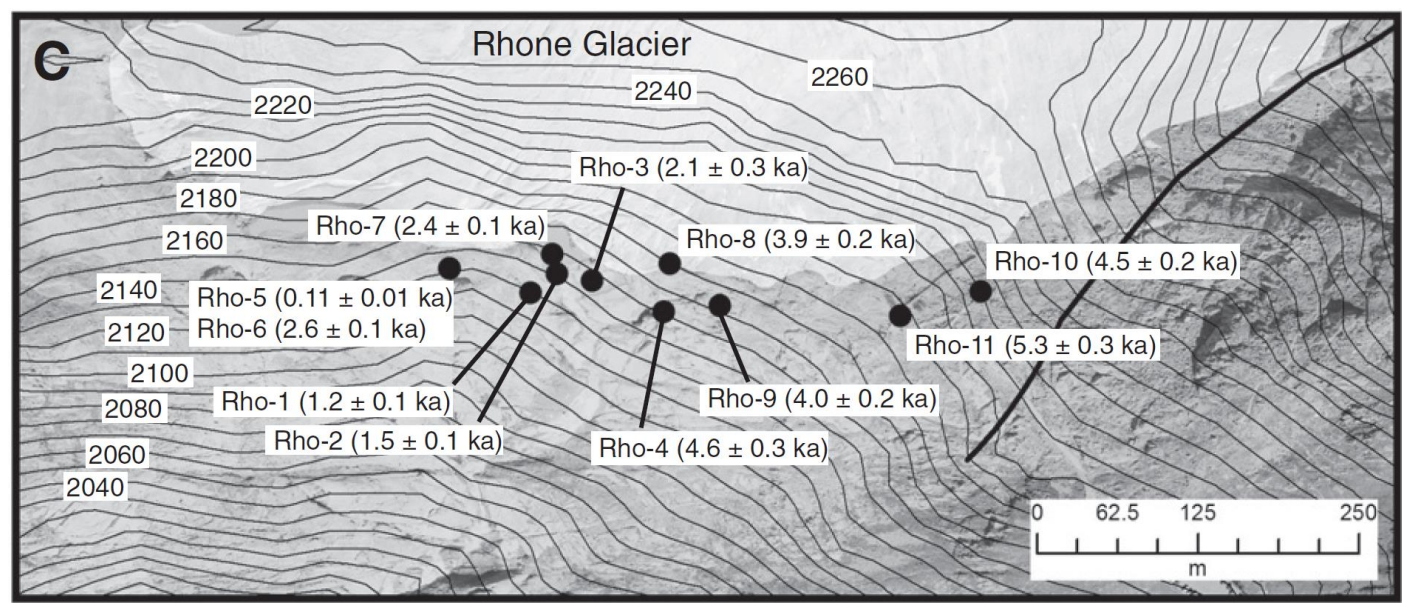

Figure 3. Sampling location on exposed rocks (darker grey-shaded area) in front of the Rhone Glacier terminus (lighter grey-shaded area). Contour lines are labelled in meters a.s.l. The minimum ${ }^{10} \mathrm{Be}$ exposure ages are shown. The figure is adopted from the work of Goehring et al. [17].

A

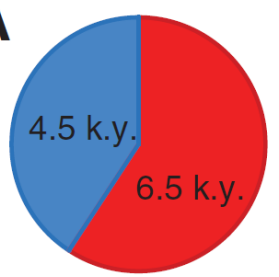

Rhone Glacier

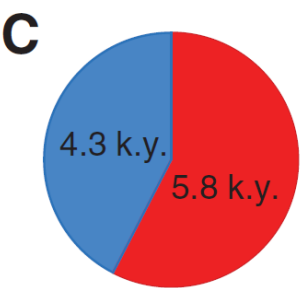

Engadine, Switzerland
B

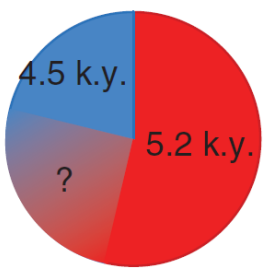

Bernina, Valais, and Grimsel Glaciers

D

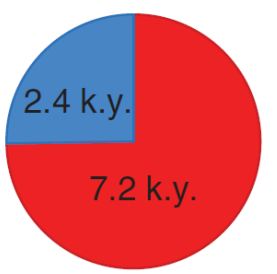

Jostedalsbreen, Norway
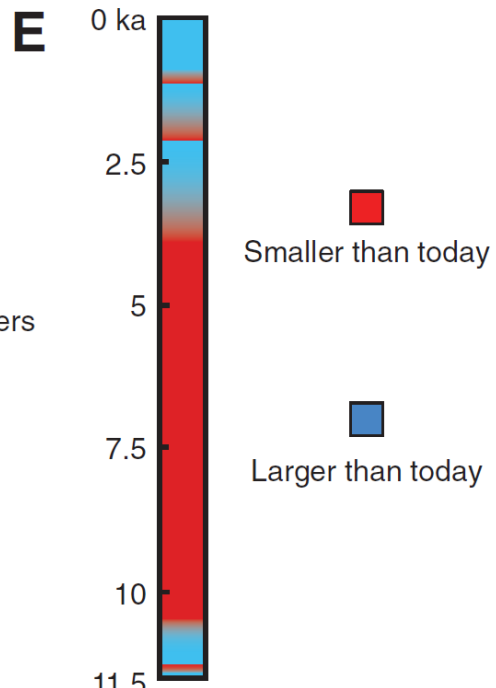

Figure 4. Schematic presentation of the time periods where European glaciers were smaller (red) and larger (blue) than today. The figure is adapted from the work of Goehring et al. [17]. "Nearby proxy records indicate that at least most of the time during which the Rhone glacier was smaller than today was during the early to mid-Holocene" [17]. In E the hypothetical Holocene advance and retreat scenario of the Rhone Glacier is displayed, indicating the glacier was smaller than today during the first part of the Holocene. 
There is also evidence that the ice of the Jostedalsbreen, the largest mountain glacier in Norway, is not a left-over from the Last Ice Age, but only formed during the second half of the Holocene [40]. Although it is unlikely that the European Alps were completely ice-free in the early Holocene, the evidence for generally lower glaciation as compared to the second half of the Holocene is mounting, as indicated from the ice core result from Ortles mentioned above [36].

\subsubsection{The Mer de Glace glacier}

A detailed radiocarbon and dendrochronological study was performed by Le Roy et al. [41] at the Mer de Glace glacier in the Mont Blanc massif (Fig. 5A), the largest glacier of the French Alps. Subfossilized wood exposed at the right lateral moraine near the terminus of the glacier was investigated (Fig. 5B). It revealed 10 glacial advances during the last $\sim 3000$ years. These glacial fluctuations are similar to those observed in the Swiss Alps, although not synchronous in all aspects.

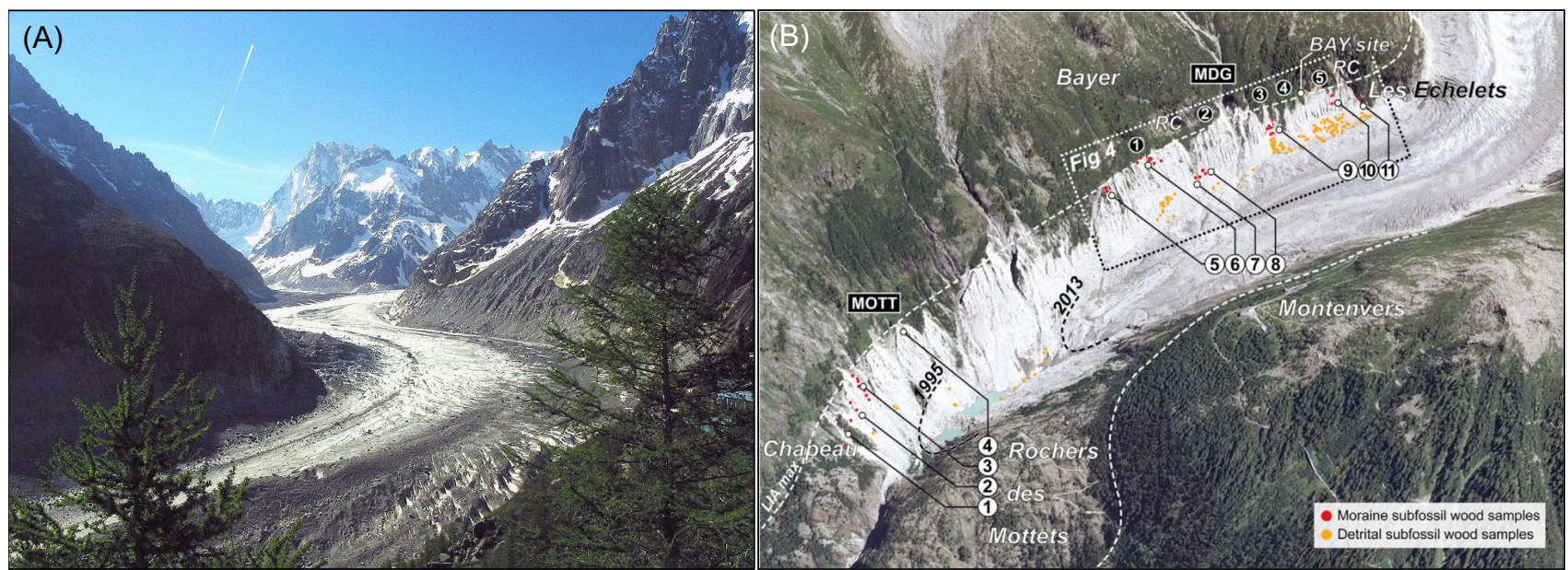

Figure 5 The lower section of the Mer de Glace glacier in the Mont Blanc mountain range, with the Grandes Jorasse (4208 $\mathrm{m}$ a.s.1.) in the background (A). The right figure (B) from the work of [41] shows the sampling sites at the right lateral moraine near the glacier terminus. Two positions of the terminus in 1995 and 2013, respectively, are marked with black dashed curves. For a detailed description of the sampling sites and the material recovered see Ref. [41].

\subsubsection{Timberline}

An important proxy for temperature changes in the Alps during the past is the timberline (sometimes also called tree line). The timberline is the edge of the habitat at which trees can grow (Fig. 6). Since precipitation in the Alps is abundant, the movement of the timberline is primarily affected by the change in summer temperature during the main growing season.

From studies of subfossil trees preserved at different altitudes, periods of higher and lower temperatures, respectively, can be reconstructed by ${ }^{14} \mathrm{C}$ measurements and dendrochronology. From studies like this (e.g. [12]), it has been estimated that the timberline moves approximately $100 \mathrm{~m}$ up or down for a summer temperature change of $\pm 0.6^{\circ} \mathrm{C}$.

\subsubsection{Temperature change during the Holocene}

In Figure 7, information on glacier and tree-line movements are summarized and converted into approximate temperature variations during the entire Holocene [22]. Glacial retreats are usually accompanied with higher timberlines indicating higher temperatures. Overall, the mean temperature went through a maximum during the first half of the Holocene, sometimes called the

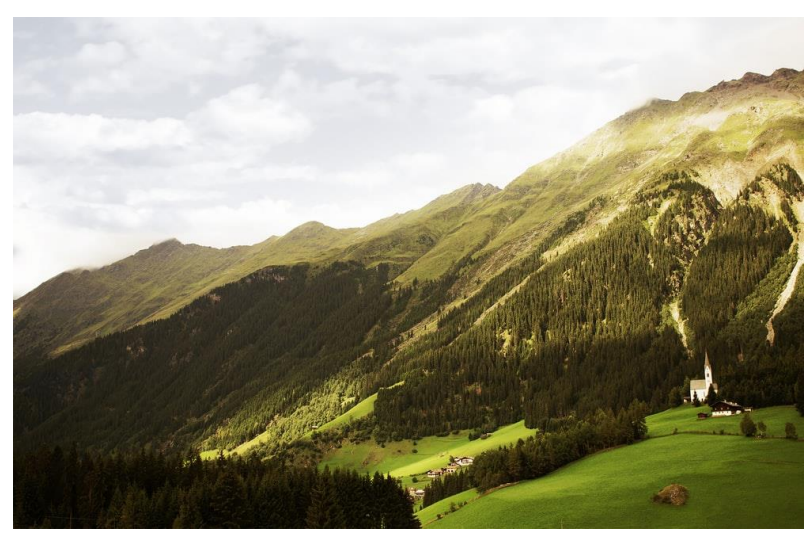

Figure 6. Typical timberline in an Alpine landscape. The transition from the forested region to grass land can be clearly seen in this picture, which is reproduced from a free download (https://unsplash.com/s/photos/timberline).

Holocene Thermal Maximum (HTM), and continuously decreased in the second half of the Holocene approaching its lowest values during the Little Ice Age (LIA) between 1300 and $1850 \mathrm{AD}$. This period also resulted in the largest glacier advance during the Holocene. The Holocene temperature trend is also supported by other temperaturesensitive proxies, e.g. by the study of chronomids in a high-altitude lake (2796 m a.s.l.) in the Austrian Alps [42]. 


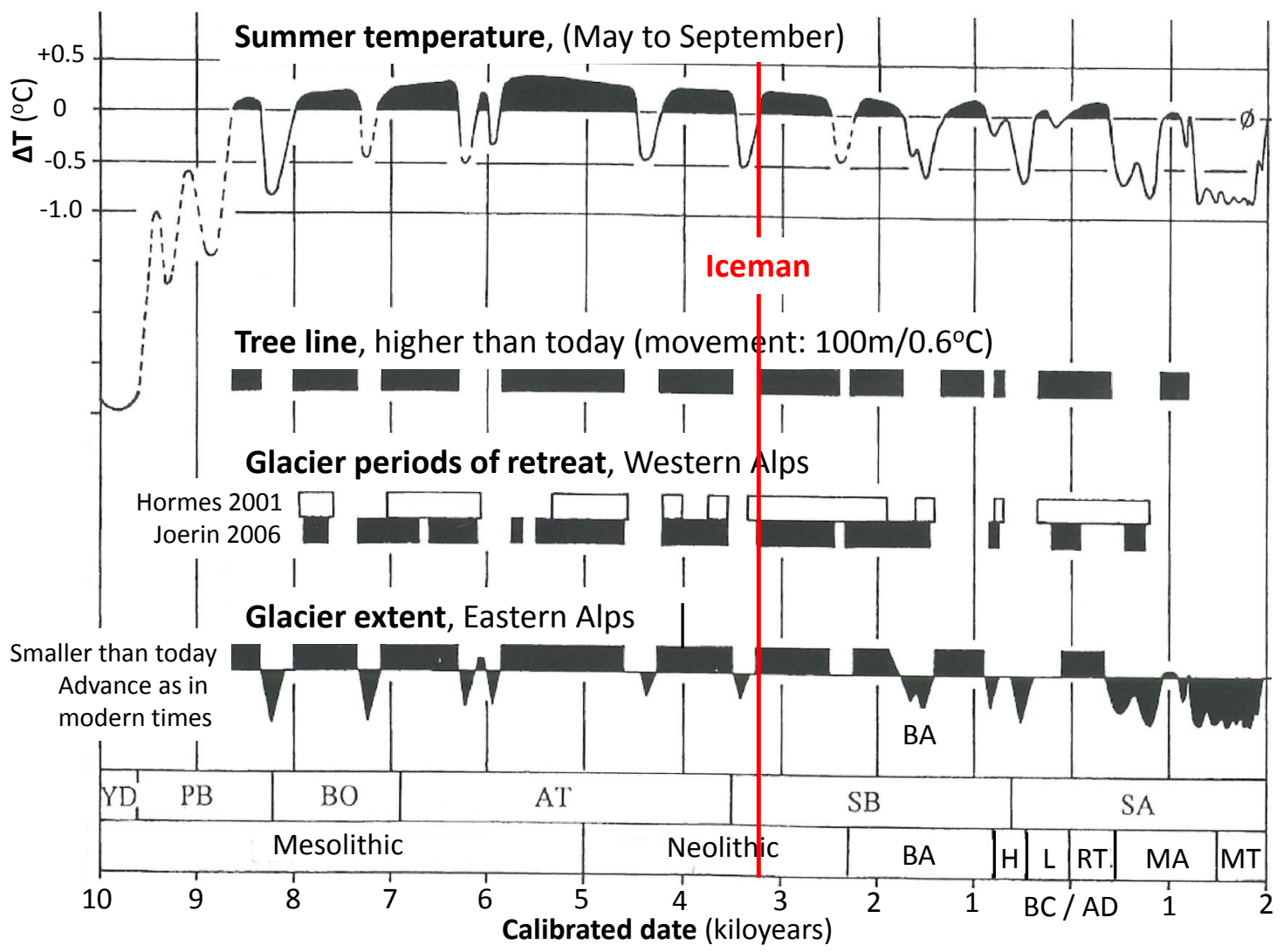

Figure 7. Schematic presentation of glacier and tree-line movements in the European Alps during the Holocene [22]. The periods of smaller glaciers and higher tree lines are indicated with the box symbols. Glacial advances are indicated with filled triangles and curves. The largest advances took place during the Little Ice Age ( AD 1300 to 1850). The top curve depicts the relative summer temperature variations deduced mainly from tree-line movements. The mean temperature between AD 1900 and 2000 is used as reference $\left(\Delta \mathrm{T}=0{ }^{\circ} \mathrm{C}\right)$. The red vertical line marks the time where the Iceman Ötzi died [43].

\subsection{The New Zealand Southern Alps}

Most of the information on Alpine glacier movements through the Holocene comes from the Northern Hemisphere. However, the New Zealand Southern Alps allow one to get information on glacier movements in the Southern Hemisphere at comparable latitudes. While Mont Blanc, the highest mountain of the European Alps (4810 m a.s.l.) is located at $45.8^{\circ} \mathrm{N}$, Aroaki/Mount Cook, the highest mountain of the NZ Southern Alps (3927 m a.s.l.) is located at $43.5^{\circ} \mathrm{S}$. Because of the closeness of the Pacific Ocean to the East and the Tasman Sea to the West of the NZ Southern Island, the glaciation of the NZ Southern Alps is more intense as compared to the European Alps, even though the latter reach up to considerably higher altitudes. Particularly the western slopes of the NZ Southern Alps, which are under the influence of the Tasman Sea and westerlies, are the home of large glaciers (e.g. Fox and Franz Josef glacier), which still reach down to about $300 \mathrm{~m}$ above sea level. Due to regional cooling, these two glaciers even advanced during a period of global warming [44].

Here, we describe two rather detailed studies of glacier movements on the eastern side the NZ Southern Alps.

\subsubsection{The Mueller glacier}

The chronology of glacier advances through the past 7000 years were reconstructed from measurements of cosmogenic in-situ produced ${ }^{10} \mathrm{Be}$ in moraines of the Mueller glacier, which is located at Mt. Sefton in the Mt. Cook mountain range [16]. Figure 8 is reproduced from this work and shows the area where the extensive ${ }^{10} \mathrm{Be}$ measurements were performed. The deduced exposure ages are listed which allow one to draw some conclusions for the glacier advances with respect to the ones in the European Alps. Interestingly, glacier advances seem not to be synchronous between the two hemispheres. Simply speaking, during some time periods glaciers advanced in the Southern Hemisphere ( $\mathrm{SH}$ ) whilst they simultaneously retreated in the Northern Hemisphere $(\mathrm{NH})$, and vice versa.

As discussed by Schaefer et al. [16], it is possible that regional effects influenced the pattern of glacier movements in this region. There is, however, some indication that the oldest ages are found for the most advanced stages of the glacier. This is more clearly seen in the chronology of moraines for the Cameron glacier discussed in the next section (3.2.2). 


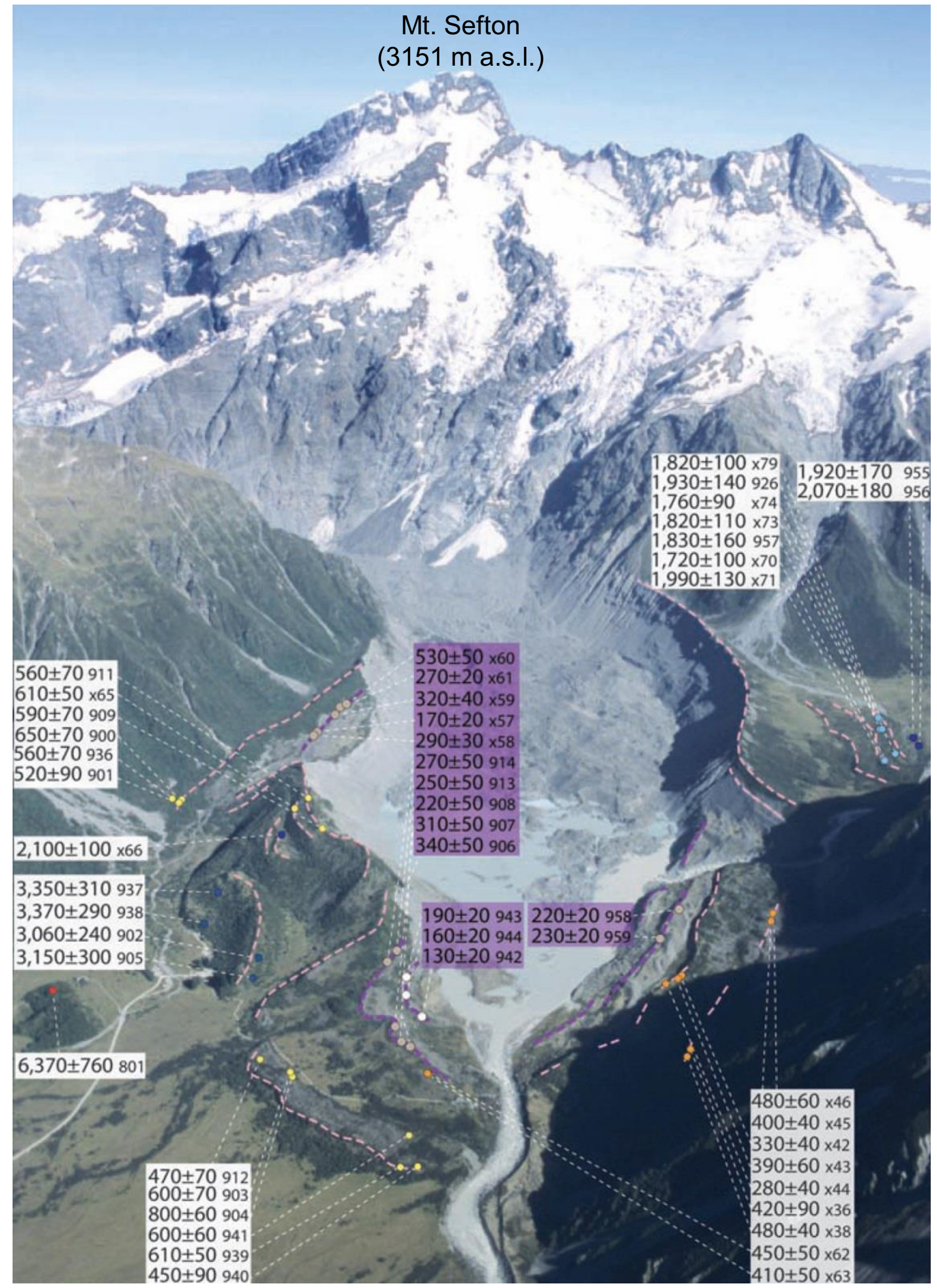

Figure 8. This figure is reproduced from Ref. [16] and shows the results of the ${ }^{10} \mathrm{Be}$ ages (given in years with $2 \sigma$ uncertainties) with the assignment to the Holocene moraines of the Mueller glacier. The ages marked in purple colour are from moraines which were deposited during mid- to late- $19^{\text {th }}$ century. 


\subsubsection{The Cameron glacier}

Another detailed study of ${ }^{10} \mathrm{Be}$ ages of moraines was performed by Putnam et al. [18] at the Cameron glacier in the Arrowsmith Range, which is a smaller mountain range parallel to the Southern Alps about $85 \mathrm{~km}$ northeast of Arioka/Mt. Cook. The altitude of the Arrowsmith Range is $\sim 1000 \mathrm{~m}$ below the highest ones of the Southern Alps, but glaciers are still abundant. Figure 9A show the main results from the work of Putnam et al. [18], where the moraines of the Cameron glacier were dated.

The detailed comparison of temperature proxies of the $\mathrm{NH}$ and $\mathrm{SH}$ displayed in Fig. 9B [18] leads to an

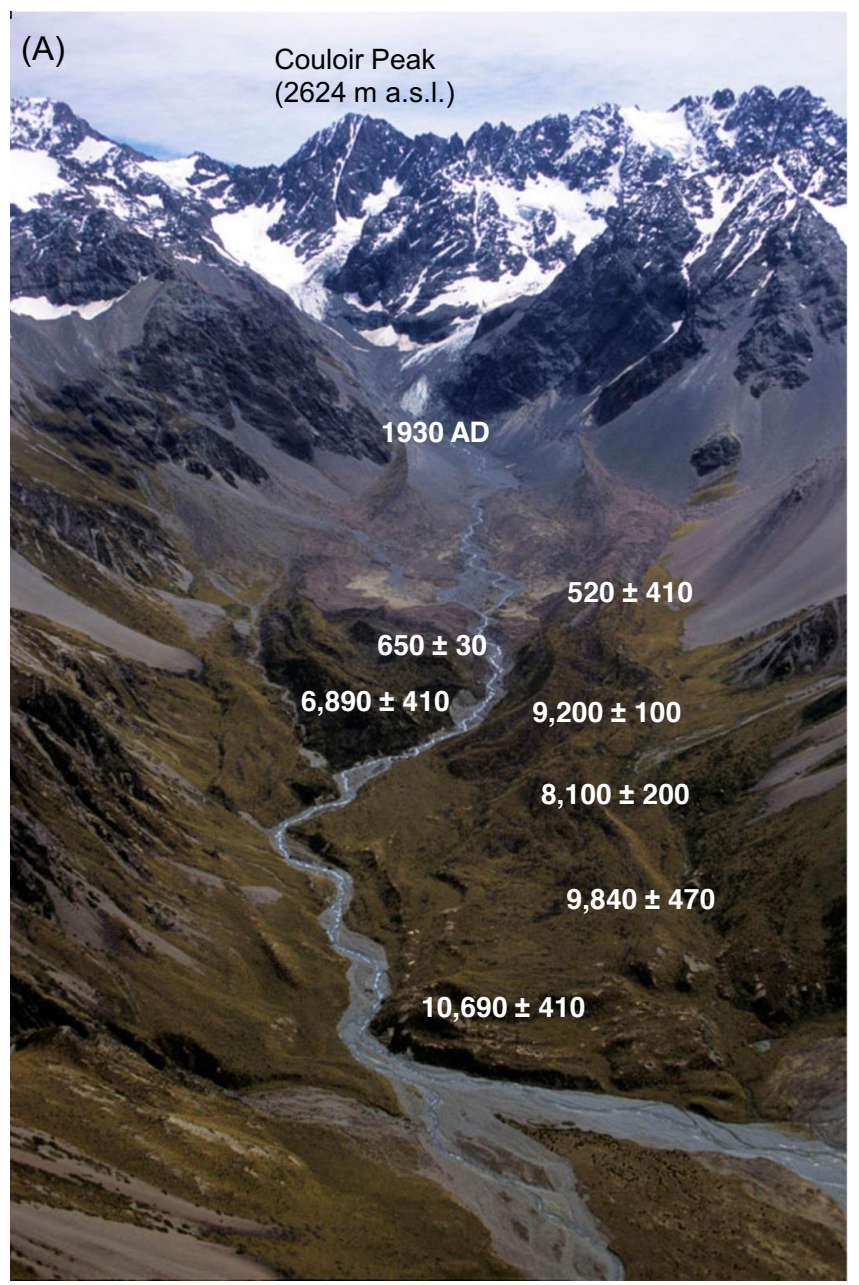

interesting conclusion. While in the $\mathrm{NH}$ the temperature in the first half of the Holcene is higher than in the second half, the opposite seems to be the case in the SH. It is interesting that this trend is supported by the insolation curves (red curves of panels $\mathrm{c}$ and $\mathrm{h}$ ) calculated from the Milankovic theory of the Earth's orbital parameter variations [45]. Although the insolation changes only by 4 to $6 \%$ over the Holocene, the general temperature trend is reproduced. A recent study to take possible effects of interannual climate variability on the observed glacier fluctuations into account, confirms the robustness of the glacier fluctuations against this short-term climate fluctuations [46].

(B)

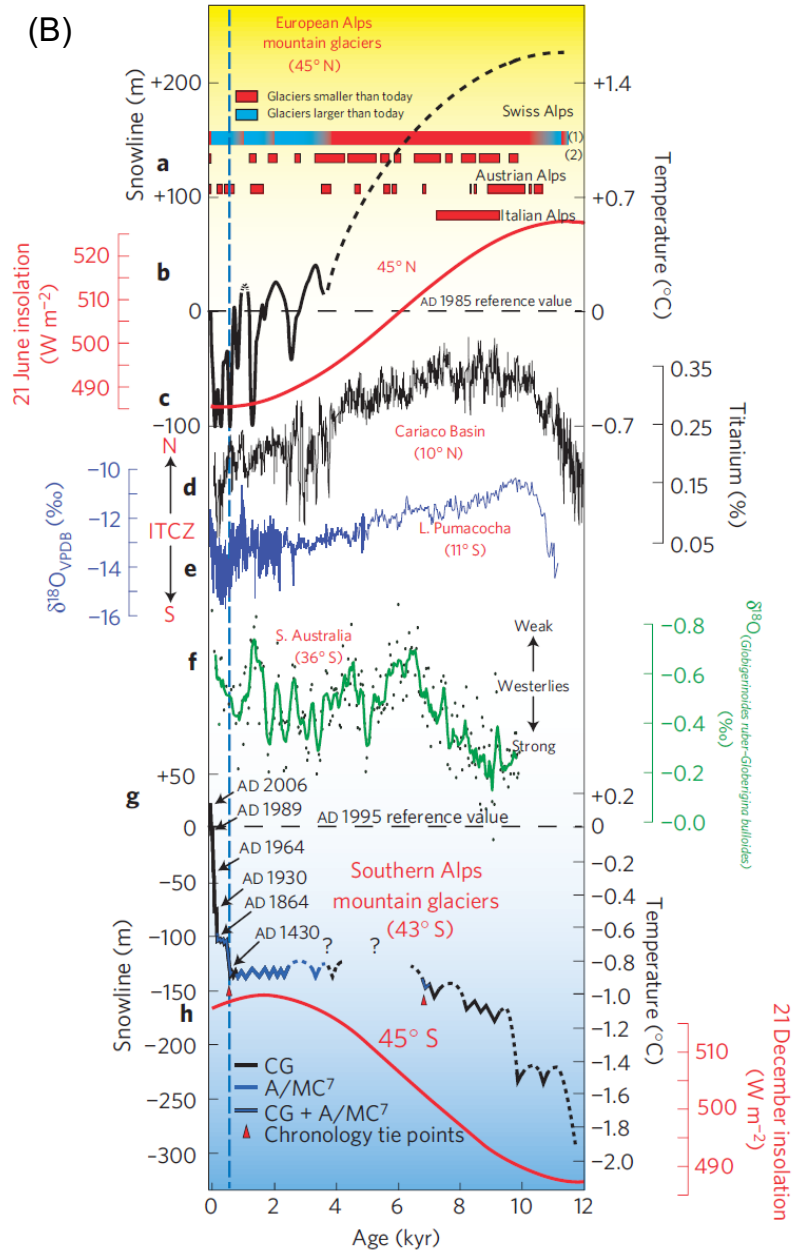

Figure 9. In Fig 9A the mean ${ }^{10} \mathrm{Be}$ ages in years (uncertainties $\pm 1 \sigma$ ) resulting from the work of Putnam et al. [18] are displayed at the Holocene moraines from the Cameron glacier. The oldest age signals the largest glacier advance at the Early Holocene. Fig. 9B shows an interesting comparison of various temperatures proxies for the NH (panels a-e) and the SH (panels f-h). For a detailed description of Fig. 9B, see Ref. [18].

\section{Conclusions}

The comparison of glacier movements throughout the Holocene from Alpine mountain ranges in the $\mathrm{NH}$ and $\mathrm{SH}$ revealed some interesting differences. The opposite temperature development from the Early to the Late Holocene in the two hemispheres is established by a number of proxies and supported by the Milankovic theory
[18]. The partly asynchronous movements of glaciers in the two hemisphere is probably influenced by regional effects [16].

This is not surprising considering that the European Alps are largely imbedded into a continental climate, whereas the NZ Southern Alps are subject to a maritime environment. 
The increasing number of reports about glacier dynamics in the past from other glaciated regions of the Northern and Southern Hemispheres, e.g. from North and South America, will help to develop a more concise picture about climatic variations around the globe during the Holocene. Concerning natural causes of the observed variations, it is unlikely that they were triggered by atmospheric $\mathrm{CO}_{2}$ because it was remarkably constant throughout the Holocene (Fig. 1 and Ref. [1]). The possible influence of solar activity variations has been discussed [47-49], but since the total solar irradiance varies by only $\sim 0.1 \%$ during the Holocene [23], other effects such as volcanic eruptions may have some influence too. In general, it seems that some amplifying terrestrial effect are needed to explain the magnitude of the observed glacier movements. It has to be seen whether the recent detailed analysis of solar activity [50] will allow one

\section{References}

[1] The Keeling Curve: https://scripps.ucsd.edu/programs/keelingcurve/

[2] S. Arrhenius, On the Influence of Carbonic Acid in the Air upon the Temperature of the Ground, Phil. Mag. J. Sci. Ser. 5, 41, 237 (1896).

[3] P. J. Crutzen and E. F. Stoermer, The Anthropocene, The Global Change Newsletters 41, 17 (2000).

[4] P. J. Crutzen, Geology of mankind, Nature 415, 23 (2002).

[5] C. N. Waters, J. Zalasiewicz, C. Summerhayes et al., The Anthropocene is functionally and stratigraphically distinct from the Holocene, Science 351, 137 (2016).

[6] J. Zalasiewicz, C. N. Waters, P. Wolfe et al., Making the case for a formal Anthropocene Epoch: an analysis of ongoing critiques, Newsletters on Stratigraphy 50(2), 205 (2017).

[7] F. Höpfel, W. Platzer, and K. Spindler, eds., Der Mann im Eis, Band 1. Bericht über das Internationale Symposium 1992 in Innsbruck, Veröffentlichungen der Universität Innsbruck 187 (1992) pp 464.

[8] B. Fowler, Iceman - Uncovering the Life and Times of a Prehistoric Man found in an Alpine Glacier, Random House, New York (2000) pp 313.

[9] W. Müller, H. Fricke, A. N. Halliday et al., Origin and migration of the Alpine Iceman, Science 302, 862 (2003).

[10] K. Nicolussi, and G. Patzelt., Discovery of EarlyHolocene wood and peat on the forefield of the Pasterze Glacier, Eastern Alps, Austria, The Holocene 10(2), 191 (2000).

[11] A. Hormes, B. U. Müller, and C. Schlüchter, The Alps with little ice: evidence for eight Holocene phases of reduced glacier extent in the Central Swiss Alps, The Holocene 11(3), 255 (2001). to draw more definite conclusions about the influence of the sun on the glacier movement during the Holocene.

One thing can be said with some certainty: The complex moving patterns of glaciers in both hemispheres of the past have now given way to an accelerated retreat of all glaciers around the globe, most likely due to the anthropogenic impact on our climate.

\section{Acknowledgement}

We have benefitted from many discussions with colleagues around the world on the issue of glacier movements. The wisdom of the late Wally Broecker on climate issues is greatly appreciated as an important input into the current work.

[12] K. Nicolussi, M. Kaufmann, G. Patzelt et al., Holcene tree-line variability in the Kauner Valley, Central Eastern Alps, indicated by dendrochronological analysis of living trees and subfossil $\log s$, Veget. Hist. Archeobot. 14, 221 (2005).

[13] U. E. Joerin, T. F. Stocker, and C. Schlüchter, Multicentury glacier fluctuations in the Swiss Alps during the Holocene, The Holocene 16, 697 (2006)

[14] M. Grosjean, P. J. Suter, M. Trachsel et al., Ice-born prehistoric finds in the Swiss Alps reflect Holocene glacier fluctuations, J. Quat. Sci. 22(3), 2003 (2007).

[15] U. E. Joerin, K. Nicolussi, A. Fischer et al., Holocene optimum events inferred from subglacial sediments at Tschierva Glacier, Eastern Alps, Quat. Sci. Rev. 27(3-4), 337 (2008).

[16] J. M. Schaefer, G. H. Denton, M. Kaplan et al., Highfrequency Holocene glacier fluctuations in New Zealand differ from the northern signature, Science 324 (5927), 622 (2009).

[17] B. M. Goehring, J. M. Schaefer, C. Schlüchter et al., The Rhone Glacier was smaller than today for most of the Holocene, Geology 39(7), 679 (2011).

[18] A. E. Putnam, J. M. Schaefer, G. H. Denton et al., Regional climate control of glaciers in New Zealand and Europe during the pre-industrial Holocene, Nature Geoscience 5, 628 (2012).

[19] I. Schimmelpfenning, J. M. Schaefer, N. Akcar et al., Holocene glacier culmination in the Western Alps and their hemispheric relevance, Geology 40, 891 (2012).

[20] I. Schimmelpfenning, J. M. Schaefer, N. Akcar et al., A chronology of Holocene and Little Ice Age glacier culminations of the Steingletscher, Central Alps, Switzerland, based on high-sensitivity beryllium-10 moraine dating, Earth Planet. Sci. Lett. 393, 220 (2014). 
[21] K. Nicolussi and C. Schlüchter, The $8.2 \mathrm{ka}$ event calendar-dated glacier response in the Alps, Geology 40(9), 819 (2014).

[22] W. Kutschera, G. Patzelt, P. Steier, and E. M. Wild, The Tyrolean Iceman and his glacial environment during The Holocene, Radiocarbon 59/2, 395 (2017).

[23] F. Steinhilber, J. Beer, and C. Fröhlich, Total solar irradiance during the Holocene, Geophys. Res. Lett. 36, L19704 (2009).

[24] A. Hormes, J. Beer, and C. Schlüchter, A geochronological approach to understand the role of solar activity on Holocene glacier length variability in the Swiss Alps, Swiss Alps Geograph. Annals 88A(4), 2281 (2006).

[25] IPCC (Intergovernmental Panel on Climate Change) Special Report on Global Warming of $1.5^{\circ} \mathrm{C}$ (2018), https://report.ipcc.ch/sr15/pdf/sr15_spm_final.pdf

[26] S. E. Koonin, Certainties and uncertainties in our energy and climate future, Schrödinger Lecture, Austrian Academy of Sciences Vienna (2018), unpublished.

[27] P. J. Crutzen, Albedo enhancement by stratospheric sulfur injections: a contribution to resolve a policy dilemma? Climate Change 77, 211 (2006).

[28] P. Ramond, Murray Gell-Man (1929-2019), Science 364, 1236 (2019).

[29] L. Augustin, C. Barbante, P. R. F. Barnes et al., Eight glacial cycles from an Antarctic ice core, Nature 429, 623 (2004).

[30] J. Jouzel, V. Masson-Delmotte, O. Cattani et al., Orbital and millennial Antarctic climate variability over the past 800,000 years, Science 317, 793 (2007).

[31] J. D. Hays, J. Imbrie, and N. J. Shackleton, Variations in the Earth's Orbit: Pacemaker of the Ice Ages, Science 194, 1121 (1976).

[32] O. Passalacqua, M. Cavitte, O. Gagliardini et al., Brief communication: Candidate sites of $1.5 \mathrm{Myr}$ old ice $37 \mathrm{~km}$ southwest of the Dome C summit, East Antarctica, The Cryosphere 12, 2167 (2018).

[33] N. B. Karlsson, T. Binder, G. Eagles et al., Glaciological characteristics in the Dome Fuji region and new assessment for "Oldest Ice", The Cryosphere 12, 2413 (2018).

[34] Temperature of Planet Earth, https://en.wikipedia.org/wiki/File:All_palaeotemps. png

[35] G. L. Foster, D. L. Royer, and D. J. Lunt, Future climate forcing potentially without precedent in the last 420 million years, Nature Comm. 8:14845 (2017).

[36] P. Gabrielli, C. Barbante, G. Bertagna et al., Age of the Mt. Ortles ice cores, the Tyrolean Iceman and glaciation of the highest summit of South Tyrol since the Northern Hemisphere Climatic Optimum, The Cryosphere 10, 2779 (2016).
[37] T. M. Jenk, S. Szidat, D. Bolius et al., A novel Radiocarbon dating technique applied to an ice core from the Alps indicating late Pleistocene ages, J. Geophys. Res. 114, D14305 (2009).

[38] D. Lal, In situ produced cosmogenic isotopes in terrestrial rocks, Annu. Rev. Earth Planet. Sci. 16, 355 (1988).

[39] J. L. Goose, and F. M. Phillips, Terrestrial in situ cosmogenic nuclides: theory and application, Quat. Sci. Rev. 20, 1475 (2001).

[40] A. Nesje, J. Bakke, S. O. Dahl et al., Norwegian mountain glaciers in the past, present and future, Glob. Planet. Change 60, 10 (2008).

[41] M. Le Roy, K. Nicolussi, P. Deline et al., Calendardated glacier variations in the western European Alps during the Neoglacial: the Mer de Glace record, Mont Blanc massif, Quat. Sci. Rev. 108, 1 (2015).

[42] E. A. Ilyashuk, K. A. Koinig, O. Heiri et al., Holocene temperature variations at a high-altitude site in the Eastern Alps: A chironomid record from Schwarzsee ob Sölden, Austria, Quat. Sci. Rev. 30, 176 (2011).

[43] W. Kutschera, G. Patzelt, E. M. Wild et al., Evidence for early human presence at high altitudes in the Ötztal Alps (Austria/Italy), Radiocarbon 56/3, 923 (2017).

[44] A. N. Mackintosh, B. M. Anderson, A. M. Lorrey et al. Regional cooling caused recent New Zealand glacier advances in a period of global warming, Nature Comms. 8, 14202 (2017).

[45] M. Milankovic, Kanon der Erdbestrahlung und seine Anwendung auf das Eiszeitenproblem, Königliche Serbische Akademie, Belgrad (1941), English translation, Canon of Insolation and the Ice-Age Problem, Belgrade (1998) pp 634.

[46] A. M. Doughty, A. N. Mackintosh, B. M. Anderson et al., An exercise in glacier length modeling: Interannual climatic variability alone cannot explain Holocene glacier fluctuations in New Zealand, Earth Planet. Sci. Lett. 470, 48 (2017).

[47] F. Steinhilber, J. A. Abreu, J. Beer et al., 9,400 years of cosmic radiation and solar activity from ice cores and tree rings, PNAS 109/16, 5967 (2012).

[48] J. A. Abreu, J. Beer, F. Steinhilber et al., ${ }^{10}$ Be in ice cores and ${ }^{14} \mathrm{C}$ in tree rings: separation of production and climate effects, Space Sci. Rev. 176(1), 343 (2013).

[49] A. P. Schurer, S. F. B. Tett, and G. C. Hegerl, Small influence of solar variability on climate over the past millennium, Nature Geoscience 7, 104 (2014).

[50] C. J. Wu, I. G. Usokin, N. Krivova et al., Solar activity over nine millennia: A consistent multi-proxy reconstruction, Astron. \& Astrophys. 615, A93 (2018). 